\title{
A NOTABLE METEOR
}

$\mathrm{O}^{\mathrm{N}}$ March 24, 1935, a bright meteor fell through the atmosphere, in a direction apparently not far from the vertical, over the Cheviots in Northumberland, about twenty miles south of Berwick. The day was a Sunday and at the time, about 7 p.m. (G.M.T.), night was beginning to fall over England. Probably because the sky was still too light, the meteor seems to have almost escaped notice in England: one observation is reported from Scarborough, and several adults and children saw it from Oldham, falling down as a vivid shooting star with a flaming tail. From Holland, Denmark and southern Norway, however, where the twilight was almost ended, many observers saw either the meteor itself, or the bright train which it left behind it; this persisted for 20-30 minutes. Prof. C. Störmer (Astrophysica Norvegica, 5, 117-138; 1939), naturally with much help from others, has collected and discussed the observations, in order to determine the location of the meteor flight, and the height and other particulars concerning its train. At first, of course, the train was straight, but it gradually became very deformed; this was possibly partly on account of its sinking downwards, but mainly because of air currents, almost horizontal, but evidently varying very much in direction at different heights along the original train. The rare cases, such as this, of persistent luminous trains of large meteors, provide one of our chief sources of information concerning the velocity and direction of the wind in the atmosphere above $70 \mathrm{~km}$., the other sources being the still rarer luminous night clouds, and the infrequent remains of polar auroras.

The most definite data obtained by Prof. Störmer for the meteor of March 24, 1935, were provided from a photograph of the train, already much distorted, taken at Grouw, in Friesland, at about 7.10 p.m., and three pastel sketches (in colours) of the distorted train, made at 7.0, 7.10 and 7.20 p.m.; these were made from a house in Stavanger, Norway. These sketches and the photograph were of special value because they showed an indented skyline (landscape or buildings) which enabled the azimuth of the meteor from Stavanger and Grouw to be determined afterwards (though with considerable labour). Other photographs showed the train as a spectacle, but contained no means of determining its azimuth so definitely.

The points Stavanger and Grouw together with the meteor train itself made an almost equilateral triangle of approximately 400 miles side. Yet from that distance the twisted trail as seen from Stavanger shone against the sky background with sharp outlines, and had the same colour and intensity as the moon. The light was steady, like electric light, and did not at all resemble the northern lights. It became increasingly distorted and at the same time it broadened and faded. By 7.30 p.m. (G.M.T.) it had entirely disappeared. It seemed to remain in the same spot all the time.

Prof. Störmer found that the top and bottom of the train were respectively about 60 and 50 miles above the ground, and that until about 7.30 p.m. it lay above the earth's shadow, so that it was illuminated by the sunlight; he concludes that the intense yellow colour of the train was due to this illumination.

As regards the meteor itself, it appears to have descended to a height of about 40 miles or less, and finally exploded with an intensely white light: the lowest part of its trail disappeared almost instantaneously. The meteor was said to have moved slowly like a rocket, its time of passage being about 5 seconds. As regards the colour of the train, one report gives it as fiery-red, another as red-yellow.

Prof. Störmer's discussion of this meteor and train is illustrated by plates showing the sketches and photographs.

\section{ANCIENT WALL-PAINTING IN SOUTHERN INDIA}

\begin{abstract}
$A \mathrm{~N}$ investigation has been conducted by $\mathrm{S}$. A Paramasivan, archæological chemist of the Government Museum, Madras, with the view of determining the technical methods employed in the wall paintings of the Kailasanatha and Vaikunthaperumal temples of Conjeevaram, the ancient Pallava eapital, and in the Bagh caves of the Vindhya Hills, Gwalior State. The last named paintings, though much mutilated and stained, still constitute "a priceless treasure comparable to those at Ajanta" (Proc. Ind. Acad. Sci., 10 , Section A, No. 2 ; 1939 . See also NATURE, 142, 757 and 143, 554).
\end{abstract}

\section{Kailasanatha and Vaikunțhaperumal Temple PAINTINGS}

The Kailasanatha paintings date from the seventheighth centuries A.D., and are on the inner walls of narrow cells lining the outer courtyard, depicting scenes from Hindu mythology. Those of the Vaikunthaperumal temple, erected by Nandivarman II (A.D. 725-790), probably date from the eighth-ninth century. They have all disappeared with the exception of a single head; but there are traces of paint everywhere.

The Pallava paintings are of the classical or Ajanta style of Hindu art. The subjects of the investigation were the carrier, the ground, the pigments and the binding medium.

Carrier. The inner walls serving as the mechanical foundation of the paintings directly supporting the ground are of sandstone, the rough surface holding the plaster fast.

Ground. Microsections showed two lines of cleavage separating three layers, (1) rough plaster, (2) fine 